
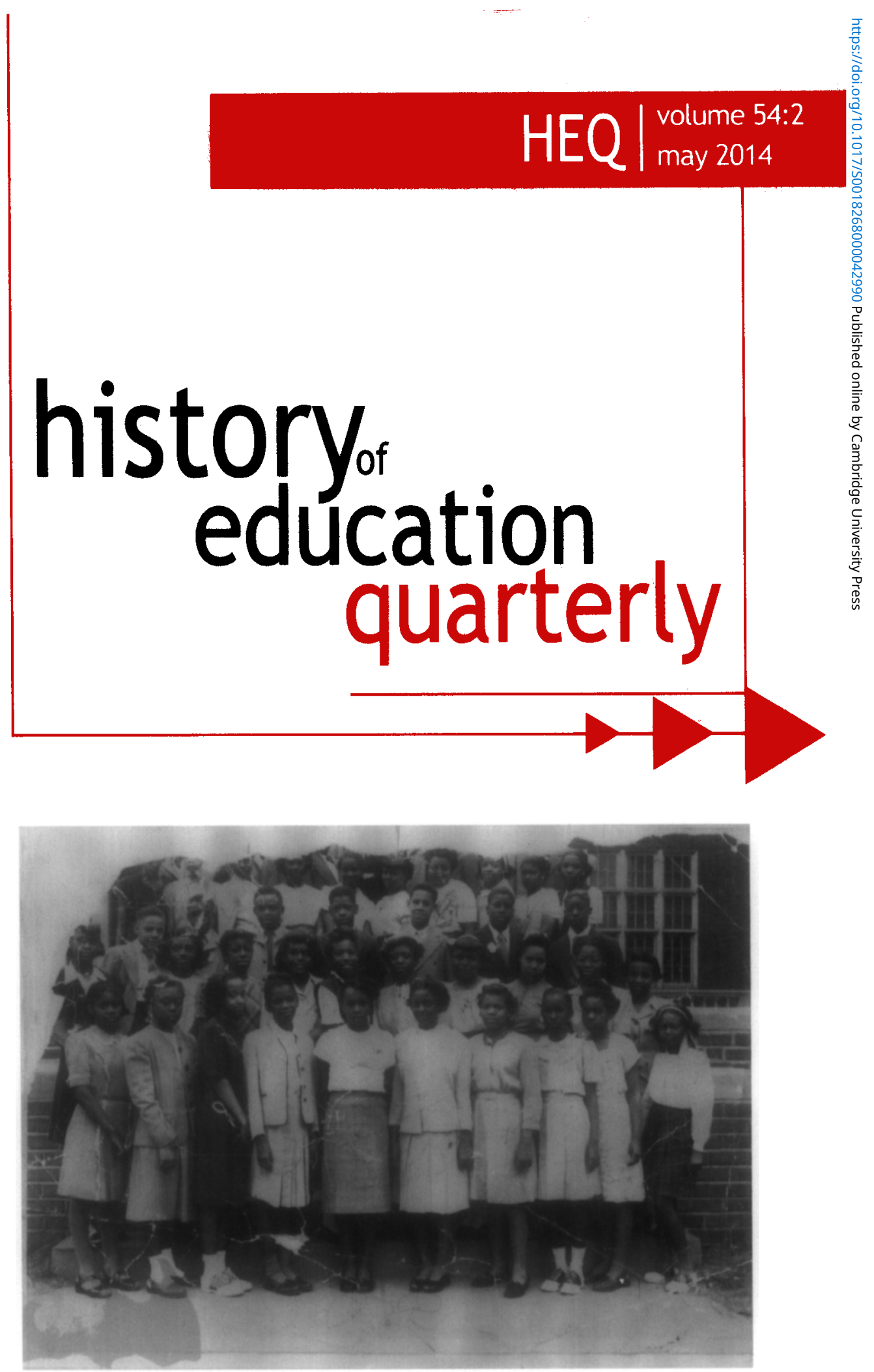
Article Submissions: Manuscripts must be submitted electronically to the History of Education Quarterly manuscript submission site, http://ojs.ed.uiuc.edu/index.php/heq/index. Questions regarding submissions can be directed to the editorial staff at heq@ed.uiuc.edu. See the last page of this issue or our website http://www.wiley.com/bw/journal.asp: ref $=0018-2680 \&$ site $=1$ for guidelines on submission. The editor will only consider articles that have been submitted exclusively to the History of Education Quarterly. It is the responsibility of the manuscript author(s) to ensure that all submissions are in accordance with our plagiarism policy, which can be found at: http://authorservices.wiley.com/bauthor/ publicationethics.asp\#_Toc149460090

Book Reviews: Assignments of reviews are made from a file of potential reviewers. To have your name added to that file. send curriculum vitae to the book review editor. Requests to review particular books cannot be honored.

HISTORY OF EDUCATION QUARTERLY (Print ISSN: 0018-2680 Online ISSN: 1748-5959) is published quarterly on behalf of the History of Education Society in conjunction with the College of Education, the University of Illinois at Urbana-Champaign, 351 Education Building, MC-708, 1310 South Sixth St., Champaign, IL 61820 by Wiley Subscription Services, Inc., a Wiley Company, 111 River St., Hoboken, NJ 07030-5774

Mailing: Periodical Postage Paid at Hoboken, $\mathrm{VJ}$ and additional offices.

Postmaster: Send all address changes to HISTORY OF EDUCATION QLARTERLY, Journal Customer Services, John Wiley \& Sons, Inc., 350 Main St., Malden, MA 02148-5020.

Publisher

History of Education Quarterly is published by Wiley Periodicals, Inc., Commerce Place, 350 Main Street, .Malden, .MA 02148; Telephone: 781388 8200; Fax: 7813888210

Journal Customer Services: For ordering information, claims and any inquiry concerning your journal subscription please go to www.wileycustomerhelp.com/ask or contact your nearest office.

Americas: Email: cs-journals@wiley.com; Tel: +17813888598 or +18008356770 (toll free in the USA \& Canada).

Europe, Middle East and Africa: Email: cs-journals@wiley.com; Tel: +44 (0) 1865778315

Asia Pacific: Email: cs-journals@wiley.com; Tel: +6565118000

Japan: For Japanese speaking support, Email: cs-japan@wiley.com; Tel: +6565118010 or Tel (toll-free): $00531650+80$

Visit our Online Customer Get-Help available in 6 languages at www.wileycustomerhelp.com

Production Editor: Muhammad Haider Bin Md. Sahle (email: HOEQ@wiley.com)

Information for Subscribers

History of Education Quarterly is published in 4 issues per year. Subscription prices for 2014 are: Institutional Print \& Online Rate: US\$189 (the Americas), US\$237 (and Rest of World), €155 (Europe), \$122 (UK). Prices are exclusive of tax Asia-Pacific GST, Canadian GST/HST and European VAT will be applied at the appropriate rates. For more information on current tax rates, please go to www.wileyonlinelibrary.com/tax-vat. The price includes online access to the current and all online back files to January 1, 2010, where available. For other pricing options, including access information and terms and conditions, please visit www.wileyonlinelibrary.com/access

Delivery Terms and Legal Title

Where the subscription price includes print issues and delivery is to the recipient's address, delivery terms are Delivered at Place (DAP); the recipient is responsible for paying any import duty or taxes. Title to all issues transfers FOB our shipping point, freight prepaid. We will endeavour to fulfil claims for missing or damaged copies within six months of publication, within our reasonable discretion and subject to availability.

Back Issues: Single issues from current and recent volumes are available at the current single issue price from csjournals@wiley.com. Earlier issues may be obtained from the Periodicals Service Company, 11 Main Street, Germantown. NY 12526, USA. Tel: +1 5185374700 , Fax: +1 5185375899 , Email: psc@periodicals.com.

\section{Copyright and Copying}

Copyright (c) 2014 History of Education Society. All rights reserved. No part of this publication may be reproduced, stored or transmitted in any form or by any means without the prior permission in writing from the copyright holder. Authorization to copy items for internal and personal use is granted by the copyright holder for libraries and other users registered with their local Reproduction Rights Organisation (RRO), e.g. Copyright Clearance Center (CCC), 222 Rosewood Drive, Danvers, MA 01923, USA (www.copyright.com), provided the appropriate fee is paid directly to the RRO. This consent does not extend to other kinds of copying such as copying for general distribution, for advertising or promotional purposes, for creating new collective works or for resale. Special requests should be addressed to: permissionsuk@wiley.com

Advertising: For advertising inquiries, please email Kristin McCarthy (email: kmccarthy@wiley.com)

\section{Disclaimer}

The Publisher, History of Education Society, and Editors cannot be held responsible for errors or any consequences arising from the use of information contained in this journal; the views and opinions expressed do not necessarily reflect those of the Publisher, History of Education Society, and Editors, neither does the publication of advertisements constitute any endorsement by the Publisher, History of Education Society, and Editors of the products advertised.

Access to this journal is available free online within institutions in the developing world through the AGORA initiative with the FAO, the HINARI initiative with the WHO and the OARE initiative with UNEP. For information, visit www.aginternetwork.org, www.healthinternetwork.org, www.oarescience.org

This journal is available online at Wiley Online Library. Visit www.wileyonlinelibrary.com to search the articles and register for table of contents email alerts.

Wiley's Corporate Citizenship initiative seeks to address the environmental, social, economic, and ethical challenges faced in our business and which are important to our diverse stakeholder groups. Since launching the initiative, we have focused on sharing our content with those in need, enhancing community philanthropy, reducing our carbon impact, creating global guidelines and best practices for paper use, establishing a vendor code of ethics, and engaging our colleagues and other stakeholders in our efforts.

Follow our progress at www.wiley.com/go/citizenship

View this journal online at wileyonlinelibrary.com/journal/hoeq

For submission instructions, subscription and all other information visit:

www.wileyonlinelibrary.com.

ISSN 0018-2680 (Print)

ISSN 1748-5959 (Online)

HISTORY OF EDUCATION QUARTERLY accepts articles for Open Access publication.

Please visit http://olabout.wiley.com/WileyCDA/Section/id-4062+1.html for further information about OnlineOpen

Printed in the USA by The Sheridan (rroup 
History of Education Quarterly

University of Illinois at Urbana-Champaign

College of Education

Education Policy, Organization and Leadership

1310 S. Sixth Street, MC-708

Champaign, IL 61820

Senior Editor

James D. Anderson, University of Illinois at Urbana-Champaign

Yoon K. Pak, Liniersity of Illinois at Urbana-Champaign

\section{Co-Editors}

Christopher M. Span,

University of Illinois at Urbana-Champaign

Book Review Editor

Timothy R. Cain, University of Georgia

Associate Editors

David Adams, Cleveland State University

Nancy Beadie, University of Washington, Seattle

Timothy Cain, University of Georgia
Kate Rousmaniere, Miami University

Eileen Tamura, University of Hawaii

Wayne Urban, University of Alabama

Paul W. Mathewson

Copy Editor and Editorial Assistants

Kevin Zayed

Book Review Editorial Assistant

Suzanne M. Reilly, University of Illinois at Urbana-Champaign

\section{Editorial Board}

\section{TERM EXPIRES IN 2015}

Dionne Danns, Indiana University

Matthew Gilbert, University of Illinois at Urbana-Champaign

Jon Hale, College of Charleston

Mary Hoffschwelle,

Middle Tennessee State University

Judith Kafka, Baruch College

David Labaree, Stanford University

Victoria-Maria MacDonald,

University of Maryland

Anne Meis Knupfer,

Purdue University

Sevan Terzian, University of Florida

Paul Theobald,

Buffalo State University

Roland Coloma,

University of Toronto
TERM EXPIRES IN 2014

Carlos Blanton,

Texas A\&M University

Benita Blessing, Ohio University

James W. Fraser,

New York University

Marybeth Gasman,

University of Pennsylvania

Karen Graves, Denison University

K. Tsianina Lomawaima,

University of Arizona

Jeffrey Mirel, University of Michigan

Kathleen Weiler, Tufts University

Joy Williamson-Lott,

University of Washington, Seattle

Robert S. Wolff,

Central Connecticut State University

Roberta Wollons,

University of Massachusetts, Boston
TERM EXPIRES IN 2013

Paul Axelrod, York University

Charles Dorn, Bowdoin College

Milton Gaither, Messiab College

Harvey Kantor, University of Utah

Hillary Moss, Amberst College

Adam Nelson, University of

Wisconsin-Madison

Christine Ogren, University oflowa

Daniel Perlstein, University of

California Berkeley

Brian Puaca,

Christopher Newport University

Rebecca Rogers,

Universite' Paris Descartes

Ann Marie Ryan,

Loyola University Chicago

Harold Wechsler,

New York University

The History of Education Society is an international scholarly society. Its purposes are to encourage and facilitate research in the history of education; to promote and improve the teaching of history of education; to encourage cooperation among specialists in history of education; and to promote an appreciation of the value of historical perspective in the making of educational policy. The Society is affiliated with the International Standing Conference for the History of Education, and members of the Society are automatically members of the Standing Conference.

Past-President
Karen Graves, Denison
University
$(2012-2013)$

Milton Gaither, Messiab College, (2010-2012)

Joy Ann Williamson, University of Washington, (2011-2013)

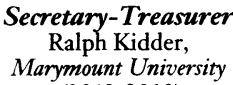

$(2012-2013)$

\author{
President-Elect \\ Jim Fraser, New York \\ University \\ (2012-2013)
}

\section{Directors}

Barbara Beatty, Wellesley College, (2012-2014)

INDIVIDUAL MEMBERSHIP: Membership is open to all persons interested in the study of the history of education. Membership provides for subscription to the History of Education Quarterly; subscription to The Network, a newsletter published jointly with Division F of the American Educational Research Association; and receipt of the program of the annual meeting of the Society. Members of the Society are automatically members of the International Standing Conference for the History of Education. Membership offers subscription to publications on a calendar-year basis only. Dues are $\$ 25$ for students, $\$ 50$ for others. Non-U.S. members should add \$7 to cover additional postage for surface mail; \$20 for airmail. To become a member, send a check for the appropriate amount in U.S. dollars only to Journal Customer Services, John Wiley \& Sons, 350 Main Street, Malden, MA 02148, USA, or to pay by credit card visit http://ordering.onlinelibrary.wiley.com/Membership.asp? ref=1748-5959\&site=1

Make checks payable to John Wiley \& Sons. Indicate preferred mailing address and the calendar year in which your subscription should begin. 


\section{History \\ of Education \\ Quarterly}

Volume 54 • Number 2 • May 2014

\section{Contents}

\section{Articles}

123 Education for Elimination in Nineteenth-Century Hawai' $i$ : Settler Colonialism and the Native Hawaiian Chiefs' Children's Boarding School

Fulie Kaomea

"The Teacher's Unexpected Bath": Plumbing the Meaning of Mayhem in the Celluloid Schoolroom

Heather A. Weaver

172 "One Can't Live on Air": Sarah McComb and the Problem of Old-Age Income for Single Women Teachers, 1870s-1930s Linda Van Ingen

197 Mountain Stereotypes, Whiteness, and the Discourse of Early School Reform in the Arkansas Ozarks, 1910s-1920s 7. Blake Perkins

\section{Book Review Essay}

222 Walker and Hollow, Soulful Bobcats: Experiences of African American Students at Obio University, 1950-1960, Cohen and Snyder, eds., Rebellion in Black and White: Southern Student Activism in the 1960s, Rogers, The Black Campus Movement: Black Students and the Racial Reconstitution of Higher Education, 1965-1972 Fulie A. Reuben 


\section{Book Reviews}

231 Cohen, Reconstructing the Campus: Higher Education and the American Civil War

Amy E. Wells Dolan

234 Cox, Segregated Soldiers: Military Training at Historically Black Colleges in the Fim Crow South

Shawn Leigh Alexander

237 Davis, Survival Schools: The American Indian Movement and Community Education in the Twin Cities

Kevin Whalen

241 K'Meyer, From Brown to Mereditb: The Long Struggle for

School Desegregation in Louisville, Kentucky, 1954-2007

Michael Fultz

243 Levin, Cold War University: Madison and the New Left in the Sixties

Robbie Lieberman

247 Schwebel, Child-Sized History: Fictions of the Past in U.S.

Classrooms

Fonna Perrillo

250 Thuesen, Greater than Equal: African American Struggles for Schools and Citizenship in North Carolina, 1919-1965

Michelle A. Purdy

For complete information on the various History of Education Society awards and deadlines, please refer to the society's official website at http://www.historyofeducation.org/.

PHOTO CREDIT: Stock image from photo.com 